\title{
The effect of migration on unionization in Austria
}

\author{
José-Ignacio Antón ${ }^{1} \cdot$ René Böheim ${ }^{2} \cdot$ Rudolf Winter-Ebmer ${ }^{3}[$ \\ Received: 5 October 2019 / Accepted: 27 January 2022 / Published online: 2 March 2022 \\ (c) The Author(s) 2022, corrected publication 2022
}

\begin{abstract}
We analyze how native employees' union membership rates change in response to foreign employees using Austrian administrative data for the period 2002 to 2012. Using an instrumental variables approach, our results indicate a negative effect of immigrant employees on native employees' unionization rates at the firm level. The negative effect is the result of a greater-mostly voluntary-turnover of unionized native employees in firms with a larger share of migrants, but it is not caused by native employees leaving unions or firms' reduced hiring of native union members.
\end{abstract}

Keywords Migration · Unions · Turnover · Hiring

JEL Classification J51 · J61 · J63

\section{Introduction}

It is important to understand how immigration and unions interact. As both immigration and de-unionization might contribute to rising inequality, it is important to know if immigration increases inequality indirectly by reducing unionization rates. Immi-

\footnotetext{
This research was funded by the NORFACE Research Programme GIWeS Global, Institutions and the Welfare State, the German Research Foundation and the Ramón Areces Foundation Grants for Research Projects in Social Sciences. Support from the Christian Doppler Laboratory "Aging, Health and the Labor Market" is also gratefully acknowledged. We thank Alex Bryson, Christian Dustmann, Laszlo Goerke, Martin Halla, Tim Hatton, and participants at various seminars and conferences for helpful comments. Franz Eder provided invaluable help with data management.

$凶 \quad$ Rudolf Winter-Ebmer rudolf.winterebmer@jku.at

1 University of Salamanca, C. Benedicto XVI, 22, 37008 Salamanca, Spain

2 WIFO, IZA and CESifo, Johannes Kepler University Linz, Altenberger Str. 69, 4040 Linz, Austria

3 IHS, IZA, CReAM and CEPR, Department of Economics, Johannes Kepler University Linz, Altenberger Str. 69, 4040 Linz, Austria
} 
gration could affect unionization for several reasons, for example, because of more ethnic diversity. Economic theory suggests a negative effect of ethnic diversity on the provision of public goods and on the preferences for redistribution (Alesina et al. 1999; Finseraas 2008; Razin et al. 2002), and empirical evidence provides support for this hypothesis (Alesina et al. 2019; Facchini et al. 2016; Luttmer 2001). The negative effect might be stronger when immigrants are culturally and religiously distant from natives or when they are economically weaker (Alesina et al. 2018). The negative effect could also affect institutions such as trade unions whose members often show solidarity, have preferences for redistribution, and who hold more positive views on immigration than the average citizen (Finseraas 2008, 2009; Rosetti 2019).

We explore whether or not more immigrant workers changed the union membership rates of native employees in Austrian private sector firms. We use matched employer-employee administrative data from Austria, 2002 to $2012 .{ }^{1}$ We use instrumental variables (IV) estimation approach to address the endogeneity of the number of immigrant employees in a firm. Following Card (2001), we use the predicted share of immigrants by district based on past settlement patterns as an instrument. ${ }^{2}$

Austria has a centralized bargaining system where almost all employees are covered by collective agreements, irrespective of being a trade union member or not (Aiginger and Guger 2005). However, unions still provide benefits for their members, for example, because workers at unionized firms have a say in personnel issues (Frandsen 2020). Indeed, mass layoffs in Austria are only legally binding if management consults the works council about whom the firm intends to lay off.

Austria experienced a strong increase in immigration and a substantial decline in union density over the last decades. The share of foreigners rose from less than $2 \%$ at the beginning of the 1970 s to roughly $11 \%$ in 2012 (Statistics Austria 2016). ${ }^{3}$ At the same time, the share of employees who are members of a trade union declined from around 60\% in 1960 to barely 27\% in 2016 (OECD 2019). This decrease is unparalleled in developed countries and the de-unionization in Austria surpasses by far the extent of de-unionization seen in, e.g., the United Kingdom, the United States or Germany. (See Fig. 1.)

Lee (2005) argues that increased heterogeneity of employees erodes the solidarity among employees and this makes it more difficult for trade unions to recruit employ-

\footnotetext{
1 We do not analyze the unionization of immigrant employees. Recruitment rates of immigrant employees are typically lower than for native employees (Defreitas 1993). Evidence from Dunlop (1958) or Ferguson (2016) suggests that unions find it difficult to recruit members when confronted with a ethnically heterogeneous workforce. Zincone and Caponio (2006) analyze the relationship between immigrants and the population of their host countries in several European states. They find that the integration of immigrants often depends more on informal and semi-informal processes mediated by institutions such as trade unions, social movements, or non-governmental organizations than on formal channels. Moreover, they highlight that labor unions have played a key role in favoring the regularization of undocumented migrants in Italy, Spain or Greece.

2 However, see Jaeger et al. (2018) who provide a critique of shift-share instruments and stress the importance to use different IV strategies depending on whether the focus is on short-term or on long-term (wage) adjustments. In our case, it is not clear if the channels through which migration affects native employees' union membership vary over time.

3 If we consider also naturalizations, the share of foreign-born persons is about $16 \%$. This number increases to approximately $19 \%$ if first- and second-generation persons are also included.
} 


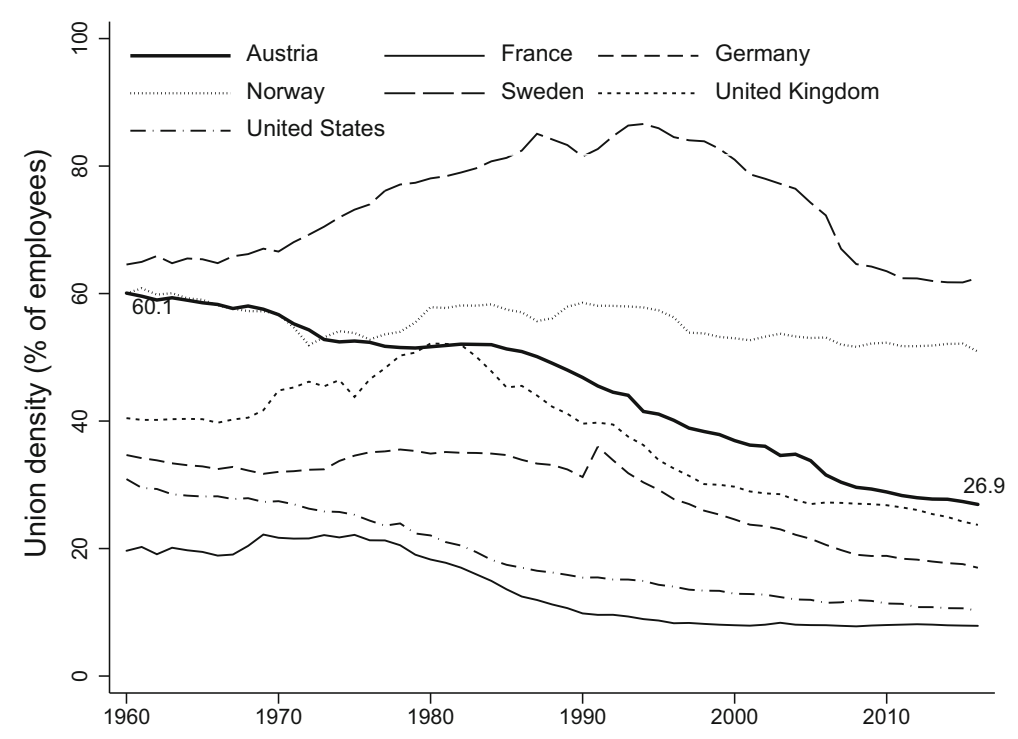

Fig. 1 Union density in Austria and selected OECD countries, 1960-2016. Source: Authors' analysis from OECD (2019) and Visser (2019)

ees. ${ }^{4}$ Native employees could stop being trade union members, or do not become members in the first place, if, for example, trade unions are seen as undermining the employees' bargaining power by supporting the free entry of immigrant employees. On the other hand, Alho (2013) suggests that the strong protectionist views of Finnish unions might have led employees with more nuanced judgments to distance themselves from trade unions.

However, the share of immigrant employees might have even a positive effect on natives' unionization rates. The "compensation hypothesis" argues that economies that are more exposed to international competition develop a greater demand for insurance and protection against new risks arising from the international integration of markets. (See, for instance, Rodrik 1998; Agell 1999, 2002 and Mayda and Rodrik 2005.) In addition, if trade unions increase their efforts to recruit immigrant employees, the recruitment drives could increase the membership rates of native employees, too. Alternatively, if native employees see unions protecting them against competition from immigrant employees, they might become trade union members more readily.

The available evidence on the impact of immigration on union membership is mixed and almost exclusively based on aggregate data. In the US, immigrant workers joined unions more readily than in European countries, and immigrants trust unions more than natives (Gorodzeisky and Richards 2020). Both declining unionization as well as more immigration increase economic inequality (Card 2009). In a new paper, Farber et al. (2021) show that declining unionization has contributed considerably towards greater income inequality in the U.S. Lee (2005) and Dreher and Gaston (2007) esti-

\footnotetext{
4 Increased employee mobility across Europe and especially so-called posted workers raised concerns among trade unions who fear "social dumping" might undermine industrial relations (Afonso and Devitt 2016; Lillie 2010).
} 
mate a negative association of immigration on union membership rates, while Brady (2007) estimates a positive one. Brady (2007) states that "the relationship between immigration and unionization is not robust, and the safest conclusion is that there is no relationship" (p89). Similarly, Vachon et al. (2016) find no empirical relationship between the two.

Potrafke (2013, 2010) and Magnani and Prentice (2003) study the impact of globalization - where migration is one part of their analysis - on union density and do not obtain conclusive evidence. Burgoon et al. (2010) find no evidence for an empirical association between immigration and trade union membership in a time-series analysis for the United States. Finseraas et al. (2020) - the only work we are aware of that uses micro-data - do not find a negative effect of immigration on union density in the construction sector in Norway.

Gächter (2000) describes the Austrian trade unions' stance towards immigrant employees as protectionist, insisting that "trade unions never accepted that foreigners might have a right to maintain in the country" (p. 84). Such a view might have been caused by Austria's guest-worker system that was introduced to (temporarily) meet increased labor demand in the 1960s and 1970s. Gächter (1995) claims that since Austria's trade unions were central to policymaking they were able to design laws to guard native employees against competition from foreigners. In consequence, Austria's trade unions opposed, for example, the free movement of labor following the European Union enlargement in 2004 (Krings 2009). During the last decade, the attitude of Austrian unions towards immigrant employees has remained essentially unchanged (Gächter 2017). ${ }^{5}$

There is a substantial body of research that identifies several factors that are related to the decline of union membership in developed countries. The available evidence highlights the decline of union-administered unemployment insurance schemes (the so-called Ghent system), a lower presence at the workplace, changed social capital or stronger effects of business cycles (Bryson et al. 2011; Schnabel 2013).

We concentrate on an analysis of the impact of immigration on the unionization of native employees. However, since immigrant employees have a lower likelihood of becoming trade union members than native employees, the overall impact of migrant inflows on union membership consists not only of the effect on natives' membership but also includes a compositional element. ${ }^{6}$ Overall, Schnabel (2020) stresses that it is an open question whether more immigration led to a de-unionization or if other factors, such as unions' failure to recruit immigrant workers, are the reason for the declining union membership rates.

We estimate that more immigrant employees in a firm lower the union density of native employees in that firm. The main channels behind the change are separations.

\footnotetext{
5 Recent empirical evidence suggests a causal effect of the increase in the migrant population and the votes for the extreme right in Austria (Halla et al. 2017). The increase in the number of foreigners also led natives to view the impact of immigration as more negative than in other European countries (Norwegian Centre for Research Data 2014).

${ }^{6}$ Schnabel and Wagner (2007), Gorodzeisky and Richards (2013), and Kranendonk and Beer (2016) analyze union membership rates between migrants and natives in several European countries using individual crosssectional data. Overall, the size of the gap varies across countries. The gap in union membership tends to be smaller in fragmented regimes (i.e., Central Europe) than in organized corporatist ones (i.e., Nordic countries).
} 
Table 1 Descriptive statistics. Source: Authors' analysis from ASSD.

\begin{tabular}{|c|c|c|c|c|}
\hline \multirow{4}{*}{ Share of unionized natives } & \multicolumn{4}{|c|}{ Means (standard deviations) } \\
\hline & \multirow{2}{*}{\multicolumn{2}{|c|}{$\frac{\text { Sample 2002-2007 }}{\text { Beginning End }}$}} & \multirow{2}{*}{\multicolumn{2}{|c|}{$\frac{\text { Sample 2007-2012 }}{\text { Beginning End }}$}} \\
\hline & & & & \\
\hline & $\begin{array}{l}0.248 \\
(0.318)\end{array}$ & $\begin{array}{l}0.208 \\
(0.288)\end{array}$ & $\begin{array}{l}0.214 \\
(0.293)\end{array}$ & $\begin{array}{l}0.199 \\
(0.284)\end{array}$ \\
\hline Share of unionized male natives & $\begin{array}{l}0.298 \\
(0.345)\end{array}$ & $\begin{array}{l}0.254 \\
(0.317)\end{array}$ & $\begin{array}{l}0.263 \\
(0.322)\end{array}$ & $\begin{array}{l}0.249 \\
(0.316)\end{array}$ \\
\hline Share of unionized female natives & $\begin{array}{l}0.158 \\
(0.257)\end{array}$ & $\begin{array}{l}0.126 \\
(0.223)\end{array}$ & $\begin{array}{l}0.128 \\
(0.225)\end{array}$ & $\begin{array}{l}0.112 \\
(0.207)\end{array}$ \\
\hline Share of unionized white-collar natives & $\begin{array}{l}0.182 \\
(0.261)\end{array}$ & $\begin{array}{l}0.146 \\
(0.225)\end{array}$ & $\begin{array}{l}0.152 \\
(0.234)\end{array}$ & $\begin{array}{l}0.139 \\
(0.222)\end{array}$ \\
\hline Share of unionized blue-collar natives & $\begin{array}{l}0.337 \\
(0.396)\end{array}$ & $\begin{array}{l}0.295 \\
(0.371)\end{array}$ & $\begin{array}{l}0.302 \\
(0.373)\end{array}$ & $\begin{array}{l}0.289 \\
(0.372)\end{array}$ \\
\hline Share of unionized natives aged $16-29$ & $\begin{array}{l}0.157 \\
(0.273)\end{array}$ & $\begin{array}{l}0.137 \\
(0.248)\end{array}$ & $\begin{array}{l}0.141 \\
(0.254)\end{array}$ & $\begin{array}{l}0.154 \\
(0.268)\end{array}$ \\
\hline Share of unionized natives aged $30-44$ & $\begin{array}{l}0.244 \\
(0.317)\end{array}$ & $\begin{array}{l}0.190 \\
(0.280)\end{array}$ & $\begin{array}{l}0.195 \\
(0.285)\end{array}$ & $\begin{array}{l}0.173 \\
(0.269)\end{array}$ \\
\hline Share of unionized natives aged 45-64 & $\begin{array}{l}0.348 \\
(0.362)\end{array}$ & $\begin{array}{l}0.290 \\
(0.333)\end{array}$ & $\begin{array}{l}0.301 \\
(0.337)\end{array}$ & $\begin{array}{l}0.258 \\
(0.318)\end{array}$ \\
\hline Share of unionized native stayers & $\begin{array}{l}0.283 \\
(0.337)\end{array}$ & $\begin{array}{l}0.277 \\
(0.330)\end{array}$ & $\begin{array}{l}0.245 \\
(0.315)\end{array}$ & $\begin{array}{l}0.256 \\
(0.319)\end{array}$ \\
\hline Separation rate for natives ( 5 years) & & $\begin{array}{l}0.415 \\
(0.200)\end{array}$ & & $\begin{array}{l}0.427 \\
(0.193)\end{array}$ \\
\hline Separation rate for unionized natives ( 5 years) & & $\begin{array}{l}0.082 \\
(0.122)\end{array}$ & & $\begin{array}{l}0.074 \\
(0.108)\end{array}$ \\
\hline Hiring rate for natives ( 5 years) & & $\begin{array}{l}0.481 \\
(1.969)\end{array}$ & & $\begin{array}{l}0.447 \\
(0.896)\end{array}$ \\
\hline Hiring rate for unionized natives ( 5 years) & & $\begin{array}{l}0.060 \\
(0.953)\end{array}$ & & $\begin{array}{l}0.056 \\
(0.345)\end{array}$ \\
\hline Involuntary separation rate for unionized natives ( 5 years) & & $\begin{array}{l}0.018 \\
(0.040)\end{array}$ & & $\begin{array}{l}0.015 \\
(0.036)\end{array}$ \\
\hline Early-retirement separation rate for unionized natives (5 years) & & $\begin{array}{l}0.026 \\
(0.041)\end{array}$ & & $\begin{array}{l}0.027 \\
(0.044)\end{array}$ \\
\hline Other separations of unionized natives ( 5 years) & & $\begin{array}{l}0.038 \\
(0.078)\end{array}$ & & $\begin{array}{l}0.032 \\
(0.061)\end{array}$ \\
\hline Share of immigrants & $\begin{array}{l}0.122 \\
(0.143)\end{array}$ & $\begin{array}{l}0.139 \\
(0.149)\end{array}$ & $\begin{array}{l}0.138 \\
(0.149)\end{array}$ & $\begin{array}{l}0.161 \\
(0.158)\end{array}$ \\
\hline Predicted share of immigrants in the district (Census 1971) & $\begin{array}{l}0.103 \\
(0.067)\end{array}$ & $\begin{array}{l}0.114 \\
(0.075)\end{array}$ & $\begin{array}{l}0.114 \\
(0.075)\end{array}$ & $\begin{array}{l}0.132 \\
(0.086)\end{array}$ \\
\hline Predicted share of immigrants in the district (Census 1981) & $\begin{array}{l}0.098 \\
(0.068)\end{array}$ & $\begin{array}{l}0.108 \\
(0.075)\end{array}$ & $\begin{array}{l}0.108 \\
(0.074)\end{array}$ & $\begin{array}{l}0.126 \\
(0.085)\end{array}$ \\
\hline
\end{tabular}


Table 1 continued

\begin{tabular}{|c|c|c|c|c|}
\hline & \multicolumn{4}{|c|}{ Means (standard deviations) } \\
\hline & \multicolumn{2}{|c|}{ Sample 2002-2007 } & \multicolumn{2}{|c|}{ Sample 2007-2012 } \\
\hline & Beginning & End & Beginning & End \\
\hline Predicted share of immigrants in the district (Census 1991) & $\begin{array}{l}0.096 \\
(0.057)\end{array}$ & $\begin{array}{l}0.106 \\
(0.063)\end{array}$ & $\begin{array}{l}0.106 \\
(0.063)\end{array}$ & $\begin{array}{l}0.124 \\
(0.072)\end{array}$ \\
\hline Share of female natives & $\begin{array}{l}0.359 \\
(0.269)\end{array}$ & $\begin{array}{l}0.362 \\
(0.268)\end{array}$ & $\begin{array}{l}0.365 \\
(0.273)\end{array}$ & $\begin{array}{l}0.367 \\
(0.271)\end{array}$ \\
\hline Share of white-collar natives & $\begin{array}{l}0.577 \\
(0.329)\end{array}$ & $\begin{array}{l}0.582 \\
(0.328)\end{array}$ & $\begin{array}{l}0.590 \\
(0.331)\end{array}$ & $\begin{array}{l}0.601 \\
(0.329)\end{array}$ \\
\hline Share of natives aged 16-29 & $\begin{array}{l}0.268 \\
(0.148)\end{array}$ & $\begin{array}{l}0.252 \\
(0.141)\end{array}$ & $\begin{array}{l}0.256 \\
(0.146)\end{array}$ & $\begin{array}{l}0.247 \\
(0.137)\end{array}$ \\
\hline Share of natives aged $45-64$ & $\begin{array}{l}0.264 \\
(0.134)\end{array}$ & $\begin{array}{l}0.312 \\
(0.141)\end{array}$ & $\begin{array}{l}0.307 \\
(0.143)\end{array}$ & $\begin{array}{l}0.361 \\
(0.151)\end{array}$ \\
\hline Average years of experience of natives & $\begin{array}{l}16.688 \\
(3.758)\end{array}$ & $\begin{array}{l}18.309 \\
(4.020)\end{array}$ & $\begin{array}{l}18.134 \\
(4.150)\end{array}$ & $\begin{array}{l}19.319 \\
(4.207)\end{array}$ \\
\hline Average years of tenure of natives & $\begin{array}{l}7.029 \\
(4.210)\end{array}$ & $\begin{array}{l}7.794 \\
(4.064)\end{array}$ & $\begin{array}{l}6.848 \\
(4.382)\end{array}$ & $\begin{array}{l}7.762 \\
(3.998)\end{array}$ \\
\hline District unemployment rate & $\begin{array}{l}0.083 \\
(0.029)\end{array}$ & $\begin{array}{l}0.081 \\
(0.028)\end{array}$ & $\begin{array}{l}0.082 \\
(0.028)\end{array}$ & $\begin{array}{l}0.089 \\
(0.027)\end{array}$ \\
\hline No. of firms & 28,984 & & 30,749 & \\
\hline
\end{tabular}

A lower number of observations involved in the calculations of the union density among specific population groups. All observations are weighted by the number of native employees, apart from separations, which are weighted by the number of natives at the beginning of the period.

Separation (hiring) rate $=$ No. of native leavers (newcomers) $/$ No. of natives at the beginning of the period. Separation (hiring) rate for unionized natives $=$ No. of unionized native leavers (newcomers)/No. of natives at the beginning of the period

We estimate an increased rate of firm-to-firm transitions coupled with the termination of union membership, and more early retirement. ${ }^{7}$

\section{Data and methods}

\subsection{Data}

Our empirical analysis uses data from the Austrian Social Security Database (ASSD). The dataset comprises labor market and demographic information on all private sector employees from 1972 to 2012 through the combination of different administrative tax, labor market, and population registers available in Austria (Zweimüller et al. 2009).

\footnotetext{
${ }^{7}$ It is likely that these separations were initiated by the employees; however, we do not observe firms' hiring practices and cannot rule out employer-induced separations. 


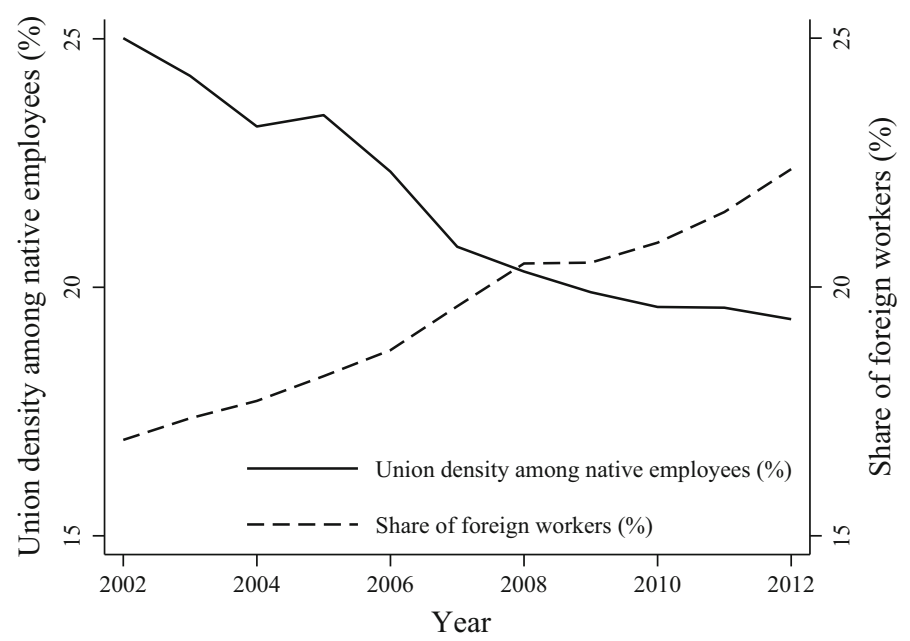

Fig. 2 Union density among native employees and share of immigrant employees in Austria, 2002-2012. Source: Authors' analysis from ASSD

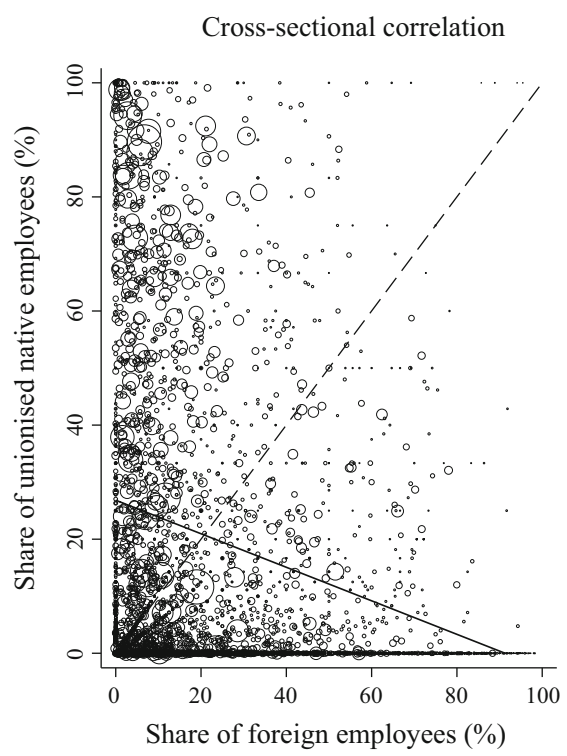

Fitted values

\section{Correlation of changes}

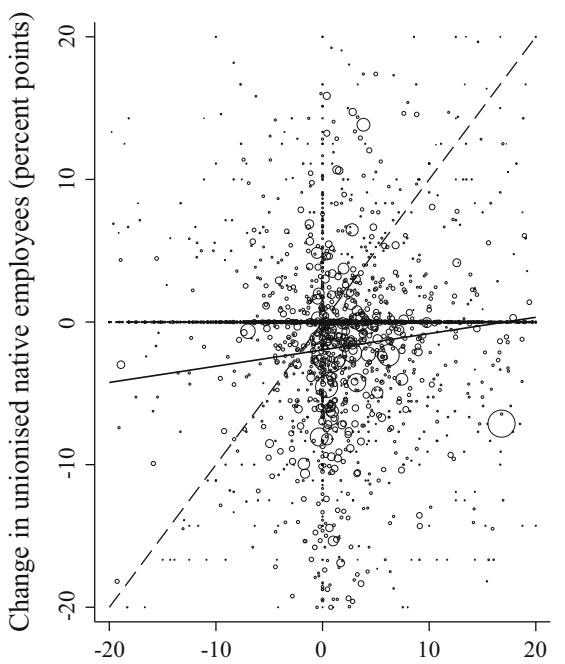

Change in foreign employees (percent points)

Fig. 3 Correlation between union density among natives and share of immigrants at the firm level in Austria, 2002, 2007 and 2012. Notes: For clarity, the figure is based on a 10\% random sample of the data. Data are weighted by the number of native employees at the firm in the left panel and by the number of native employees at the beginning of the sub-period in the right one. Source: Authors' analysis from ASSD. 
Table 2 Determinants of the share of unionized natives in Austria, regression in changes, 2002-2007 and 2007-2012. Source: Authors' analysis from ASSD

\begin{tabular}{|c|c|c|c|c|}
\hline & (I) & (II) & (III) & (IV) \\
\hline & OLS & IV-Census 1971 & IV-Census 1981 & IV-Census 1991 \\
\hline \multirow{2}{*}{$\begin{array}{l}\text { Change in the share of immigrant } \\
\text { employees }\end{array}$} & $0.036^{*}$ & $-0.512 * * *$ & $-0.492 * *$ & $-0.648 * * *$ \\
\hline & $(0.020)$ & $(0.181)$ & $(0.198)$ & $(0.239)$ \\
\hline \multirow[t]{2}{*}{ Initial share of female natives } & $0.007 * *$ & $0.010 * * *$ & $0.010 * * *$ & $0.010 * * *$ \\
\hline & $(0.004)$ & $(0.004)$ & $(0.004)$ & $(0.004)$ \\
\hline \multirow[t]{2}{*}{ Initial share of white-collar natives } & -0.001 & $-0.009^{*}$ & $-0.009^{*}$ & $-0.011^{*}$ \\
\hline & $(0.004)$ & $(0.005)$ & $(0.005)$ & $(0.006)$ \\
\hline \multirow[t]{2}{*}{ Initial share of natives $16-29$} & $-0.017 * *$ & $-0.026^{* * *}$ & $-0.026^{* * *}$ & $-0.028 * * *$ \\
\hline & $(0.007)$ & $(0.007)$ & $(0.008)$ & $(0.008)$ \\
\hline \multirow[t]{2}{*}{ Initial share of natives $45-64$} & $-0.029 * * *$ & -0.004 & -0.005 & 0.002 \\
\hline & $(0.011)$ & $(0.015)$ & $(0.015)$ & $(0.015)$ \\
\hline \multirow[t]{2}{*}{ Initial average experience of natives } & $-0.003 * * *$ & $-0.004 * * *$ & $-0.004 * * *$ & $-0.005 * * *$ \\
\hline & $(0.000)$ & $(0.001)$ & $(0.001)$ & $(0.001)$ \\
\hline \multirow[t]{2}{*}{ Initial average tenure of natives } & 0.000 & -0.000 & -0.000 & -0.000 \\
\hline & $(0.000)$ & $(0.000)$ & $(0.000)$ & $(0.000)$ \\
\hline \multirow{2}{*}{$\begin{array}{l}\text { Initial district-level unemployment } \\
\text { rate }\end{array}$} & $0.093 * *$ & $0.080 *$ & $0.080 *$ & $0.076^{*}$ \\
\hline & $(0.040)$ & $(0.043)$ & $(0.042)$ & $(0.045)$ \\
\hline Adjusted $R^{2}$ & 0.028 & & & \\
\hline Wald $F$-statistic (1st stage) & & 40.819 & 19.886 & 15.856 \\
\hline Mean of the dependent variable & 0.217 & 0.217 & 0.217 & 0.217 \\
\hline Mean of the independent variable & 0.141 & 0.141 & 0.141 & 0.141 \\
\hline No. of observations & 59,733 & 59,733 & 59,733 & 59,733 \\
\hline
\end{tabular}

*** Significant at $1 \%$ level; ${ }^{* *}$ significant at $5 \%$ level; ${ }^{*}$ significant at $10 \%$ level. Standard errors clustered at the district level in parentheses. All specifications include a time-dummy for the period 2007-2012, industry and region fixed effects and an intercept. All regressions are weighted by the number of native employees at the beginning of the period

We obtain the information on union membership from administrative tax records where union dues are recorded as a separate item since they lower the tax base. Typically, Austrian union members pay their union dues through their employers who deduct them from wages and transfer them to the union. Employers are required to include this information on the tax statement. In rare cases, employees pay their union dues directly to the unions. Since union dues lower an employee's tax base, each union member has an incentive in declaring the union dues to the tax authorities.

The immigration status of employees is a combination of the information in several administrative registers. Since the registers serve different purposes, they do not necessarily contain the same information. We use the broadest possible definition of a person's immigration status: If a person is reported to have non-Austrian citizenship in any register, we consider that individual an immigrant, irrespective of eventual 
Table 3 First-stage regression for the share of immigrant employees in the firm. Source: Authors' analysis from ASSD

\begin{tabular}{|c|c|c|c|}
\hline & (I) & (II) & (III) \\
\hline & Census 1971 & Census 1981 & Census 1991 \\
\hline \multirow[t]{2}{*}{$\begin{array}{l}\text { Change in the predicted share of } \\
\text { immigrant employees (Census } \\
\text { 1971) }\end{array}$} & $0.383 * * *$ & & \\
\hline & $(0.060)$ & & \\
\hline \multirow[t]{2}{*}{$\begin{array}{l}\text { Change in the predicted share of } \\
\text { immigrant employees (Census } \\
\text { 1981) }\end{array}$} & & $0.426 * * *$ & \\
\hline & & $(0.095)$ & \\
\hline \multirow[t]{2}{*}{$\begin{array}{l}\text { Change in the predicted share of } \\
\text { immigrant employees (Census } \\
\text { 1991) }\end{array}$} & & & $0.507 * * *$ \\
\hline & & & $(0.127)$ \\
\hline \multirow[t]{2}{*}{ Initial share of female natives } & $0.005^{* *}$ & $0.005^{* *}$ & $0.005^{* *}$ \\
\hline & $(0.002)$ & $(0.002)$ & $(0.002)$ \\
\hline \multirow{2}{*}{$\begin{array}{l}\text { Initial share of white-collar } \\
\text { natives }\end{array}$} & $-0.018 * * *$ & $-0.018 * * *$ & $-0.018^{* * *}$ \\
\hline & $(0.002)$ & $(0.003)$ & $(0.002)$ \\
\hline \multirow[t]{2}{*}{ Initial share of natives $16-29$} & $-0.012 * *$ & $-0.012 * *$ & $-0.013^{* *}$ \\
\hline & $(0.005)$ & $(0.005)$ & $(0.006)$ \\
\hline \multirow[t]{2}{*}{ Initial share of natives $45-64$} & $0.042 * * *$ & $0.042 * * *$ & $0.043 * * *$ \\
\hline & $(0.006)$ & $(0.006)$ & $(0.006)$ \\
\hline \multirow{2}{*}{$\begin{array}{l}\text { Initial average experience of } \\
\text { natives }\end{array}$} & $-0.003 * * *$ & $-0.003 * * *$ & $-0.003 * * *$ \\
\hline & $(0.000)$ & $(0.000)$ & $(0.000)$ \\
\hline \multirow[t]{2}{*}{ Initial average tenure of natives } & $-0.001 * * *$ & $-0.001 * * *$ & $-0.001 * *$ \\
\hline & $(0.000)$ & $(0.000)$ & $(0.000)$ \\
\hline \multirow{2}{*}{$\begin{array}{l}\text { Initial district-level } \\
\text { unemployment rate }\end{array}$} & 0.042 & 0.029 & 0.024 \\
\hline & $(0.027)$ & $(0.026)$ & $(0.026)$ \\
\hline $\begin{array}{l}\text { Wald } F \text {-statistic of excluded } \\
\text { instruments }\end{array}$ & 40.819 & 19.886 & 15.856 \\
\hline Adjusted $R^{2}$ & 0.014 & 0.014 & 0.014 \\
\hline Mean of the dependent variable & 0.141 & 0.141 & 0.141 \\
\hline Mean of the independent variable & 0.117 & 0.110 & 0.109 \\
\hline No. of observations & 59,733 & 59,733 & 59,733 \\
\hline
\end{tabular}

*** Significant at $1 \%$ level; ** significant at $5 \%$ level; *significant at $10 \%$ level. Standard errors clustered at the district level in parentheses. All specifications include the initial share of female natives, the initial share of white-collar natives, the initial share of natives aged 16-29 and 45-64, the initial district-level unemployment rate, a time-dummy for the period 2007-2012, industry and region fixed effects and an intercept. All regressions are weighted by the number of native employees at the beginning of the period 
Table 4 Effects of the share of immigrant employees on the share of unionized natives in Austria, regression in changes, 2002-2007 and 2007-2012, results by groups of native employees. Source: Authors' analysis from ASSD

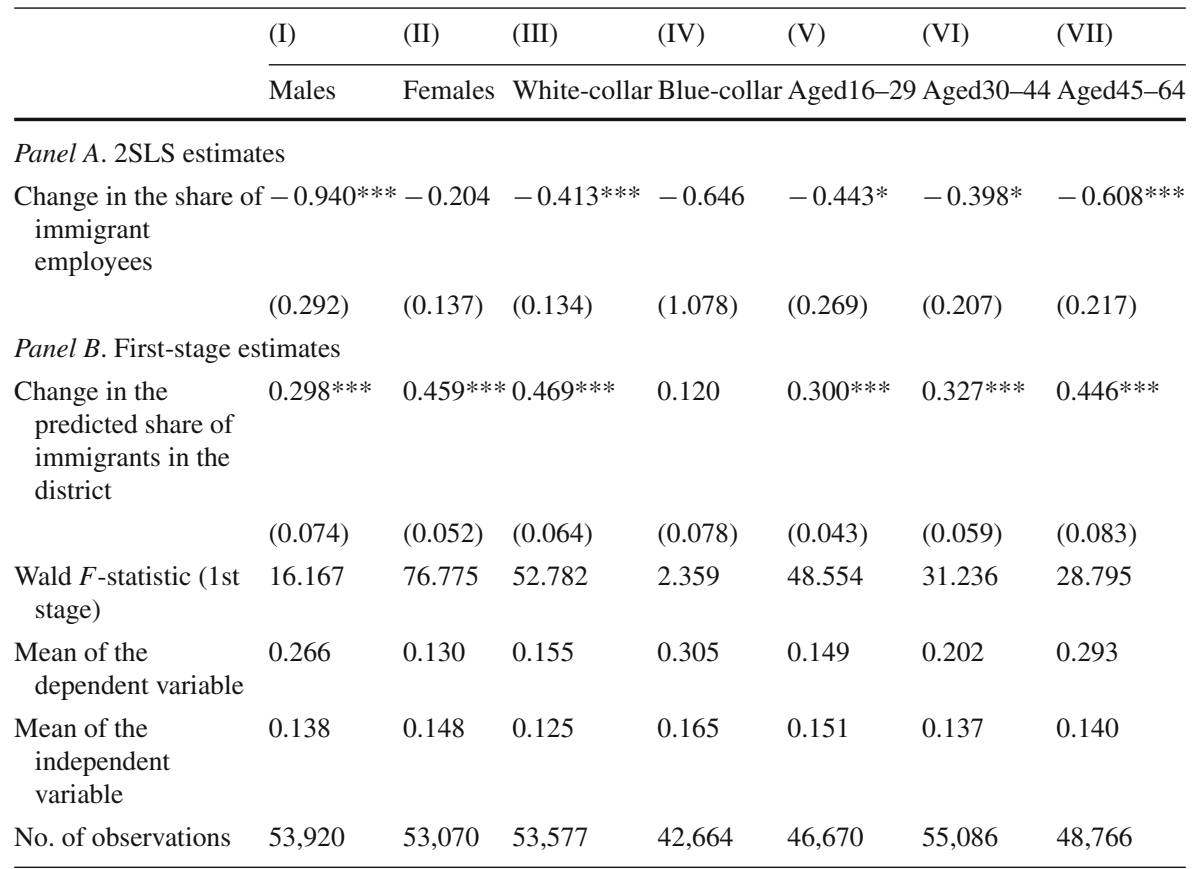

*** Significant at $1 \%$ level; ${ }^{* *}$ significant at $5 \%$ level; * significant at $10 \%$ level. Results from IV-estimates where the instrument is based on Census 1971 data. Standard errors clustered at the district level in parentheses. All specifications include the initial share of female natives, the initial share of white-collar natives, the initial share of natives aged 16-29 and 45-64, the initial district-level unemployment rate, a time-dummy for the period 2007-2012, industry and region fixed effects and an intercept. All regressions are weighted by the number of native employees of each category at the beginning of the period. The number of observations is different across the Columns, because some firms do not have this demographic group

naturalization. We believe that this broad definition more clearly reflects the possible channels through which immigration might affect union density rather than the actual legal status. ${ }^{8}$

The unit of observation is the firm, and we focus on the period 2002-2012. We focus on the union membership of native employees aged 18-64 years old in private-sector firms with ten or more employees. ${ }^{9}$ During this period, the union density declined, and the share of immigrant employees increased. Figure 2 plots the union density of native employees and the share of immigrant employees among all employees for the years 2002-2012. The native employees' union density declined from $25 \%$ in 2002 to

\footnotetext{
8 We cannot identify persons who have multiple citizenships. Austria has ius sanguinis, i.e., a child acquires Austrian citizenship through its parent. Naturalizations were rare. For example, in 1975, a total of 6,475 foreign citizens who were resident in Austria were naturalized (Statistik Austria 2021); in 2002, the number was 36,011 .

9 We exclude public administration, education and health, private household services, arts and entertainment as well as agriculture, fishing and forestry, and mining and quarrying from our sample.
} 


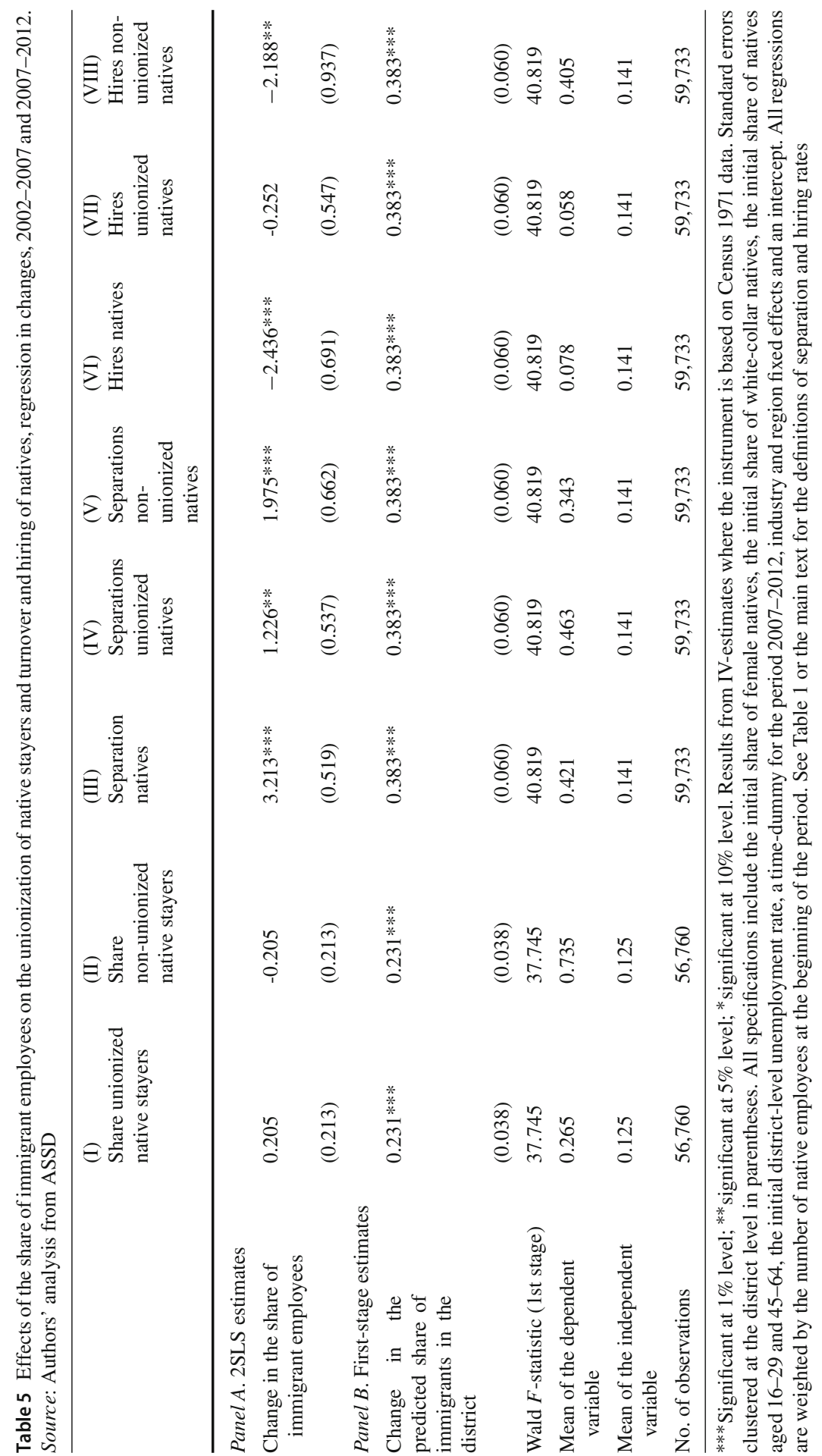


Table 6 Effects of the share of immigrant employees on different types of separations of unionized natives, regression in changes, 2002-2007 and 2007-2012. Source: Authors' analysis from ASSD

\begin{tabular}{llll}
\hline & $\begin{array}{l}\text { (I) } \\
\text { Involuntary } \\
\text { separations }\end{array}$ & $\begin{array}{c}\text { (II) } \\
\text { Early } \\
\text { retirement }\end{array}$ & $\begin{array}{c}\text { (III) } \\
\text { Other } \\
\text { separations }\end{array}$ \\
\hline $\begin{array}{l}\text { Panel A. 2SLS estimates } \\
\text { Change in the share of immigrant employees }\end{array}$ & 0.203 & $0.555^{* *}$ & $0.468^{* * *}$ \\
& $(0.148)$ & $(0.246)$ & $(0.232)$ \\
$\begin{array}{l}\text { Panel } B \text {. First-stage estimates } \\
\text { Change in the predicted share } \\
\text { of immigrants in the district }\end{array}$ & $0.383^{* * *}$ & $0.383^{* * *}$ & $0.383^{* * *}$ \\
& $(0.060)$ & & $(0.060)$ \\
Wald $F$-statistic (1st stage) & 40.819 & 40.819 & 40.819 \\
Mean of the dependent variable & 0.016 & 0.026 & 0.035 \\
Mean of the independent variable & 0.141 & 0.141 & 0.141 \\
No. of observations & 59,733 & 59,733 & 59,733 \\
\hline
\end{tabular}

***Significant at $1 \%$ level; **significant at 5\% level; *significant at $10 \%$ level. Results from IV-estimates where the instrument is based on Census 1971 data. Standard errors clustered at the district level in parentheses. All specifications include the initial share of female natives, the initial share of white-collar natives, the initial share of natives aged 16-29 and 45-64, the initial district-level unemployment rate, a time-dummy for the period 2007-2012, industry and region fixed effects and an intercept. All regressions are weighted by the number of native employees at the beginning of the period. Involuntary separations includes individuals who receive unemployment benefits during the 28 days immediately after separation. Early retirement is defined as receipt of an old-age pension, disability pensions and advances on pension payments before the statutory retirement age of 60 for women and 65 for men

$19.4 \%$ in 2012. During this period, the share of immigrant employees rose from 16.9 to about $22.4 \%$.

More than $90 \%$ of the variation of union density at the firm level is observed between firms rather than within firms. To exploit the variability of union density within establishments while controlling for time-invariant firm heterogeneity, we use an econometric specification in changes rather than in levels. To reduce the survival bias that arises if we select only firms that are present during the entire period, we split the period 2002-2012 into two different sub-periods, 2002-2007 and 2007-2012. ${ }^{10}$ The final sample has observations on 36,506 different firms and 1,674,463 different employees.

Since the share of immigrant employees in a firm is the outcome of choices, i.e., endogenous, we use an IV estimation approach where we follow the shift-share approach of Card (2001). The instrument builds on the settlements of immigrants in the past and the net inflows of immigrants by nationality and year. This information is from Statistics Austria (2016), and we concentrate on the two main migrant groups in Austria: Those who arrived from former Yugoslavia, Turkey, and a residual category of immigrants from other origins. ${ }^{11}$

\footnotetext{
10 In Table 7, we provide descriptive statistics of our sample and observations which are excluded because their firms have fewer than 10 employees or because the firms are not observed in each year 2002-2012.

11 The data on net flows for this period only allows to distinguish between these three groups.
} 


\subsection{Empirical approach}

Our main empirical specification of the impact of the share of immigrant employees in a firm on the union density of native employees follows the specifications used in recent works that explore the effect of international trade on labor markets (Autor et al. 2013, 2014; Balsvik et al. 2015; Dauth et al. 2014),

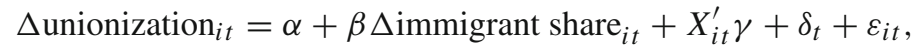

where unionization is the share of native employees who are union members among all native employees in firm $i$ at time $t$ (in \%), immigrant share it $_{i t}$ denotes the share of immigrant employees in the firm (in \%), $X_{i t}^{\prime}$ is a vector of firm characteristics (share of native women, share of white-collar native employees, share of natives aged 16-29, share of employees aged 45-64, average years of experience, average years of tenure, and the district-level unemployment rate) measured at the beginning of the period, $\delta_{t}$ is an indicator variable for the sub-period 2002-2007 or 2007-2012, and $\varepsilon_{i t}$ is an error term. In addition, we include 44 industry indicators, and nine regional indicators. ${ }^{12}$ Because our main variables of interest, union density and immigration, could be measured with error and the exact timing of reactions are not clear, we use differences over longer periods, 5-year changes, in order to increase the signal-to-noise ratio (Abowd and Freeman 1991; Bound et al. 2001; Griliches and Hausman 1986; McKinnish 2008; Meijer et al. 2015; Swaffield 2001). ${ }^{13}$

To identify channels through which the presence of immigrants may influence natives' union membership rates, we also explore the effect of the share of immigrant employees the separation rates and hiring rates of native employees. We estimate regression models similar to the one in equation (1) but where we use different dependent variables. We use the separation rate of native employees, the separation rate of unionized native employees, the hiring rate of native employees, and the hiring rate of unionized native employees. We calculate the separation rate of native employees as the number of native employees who have left firm $i$ by the end of period $t$ as a fraction of the number of native employees who were in the firm at the beginning of period $t .{ }^{14}$

\footnotetext{
12 We also include the initial value of the variables in order to avoid further endogeneity problems, given that the inflows of immigrant employees might affect the composition of the native workforce in a firm. Nevertheless, as a robustness check, we estimate this model including the covariates in changes. See Table 8, column (I), in "Appendix."

13 Another reason for this approach is related to the relevance of our instrument which decreases in a fixed-effects specification (within-group estimator). The measurement error in union status has been widely studied, for instance, Swaffield (2001). In our case, union affiliation relies on administrative data where the status is determined by a record of paid trade union dues in a year. However, we cannot distinguish between payments made by an employee who works at different workplaces in a calendar year.

14 Our analysis of potential channels serves the purpose to separate the effects of leaving the firm versus leaving the union. We analyze the transitions separately because this allows us to use the same instrumental variables approach as in our main specification. The estimation of an, e.g., multinomial model would require still stronger assumptions (Chesher and Rosen 2017).
} 


\subsection{Identification}

The presence of immigrant employees might be correlated with unobservable factors that affect unionization at the firm level and thus bias the estimates. A bias might arise, for example, when union density depends on economic growth and immigration is also influenced by it. In the absence of a natural experiment, we resort to an IV approach. We use a version of the "shift-share" instrument, proposed by David Card (Altonji and Card 1991; Card 2001). The approach uses the predicted share of immigrants in a region, which is estimated from the distribution of immigrants across regions in an earlier year and the total net flows of immigrants since. The rationality behind the instrument is that immigrants from a certain country of origin tend to locate in the same location because of already existing social networks. ${ }^{15}$ The instrument is based on the population aged 16 and above.

Let $M_{j k t}$ and $M_{j k 0}$ be the stock of immigrants from country $j$ in district $k$ in period $t$ and 0 (the base year). The predicted stock of immigrants in district $k$ and year $t, \widehat{M_{k t}}$, is given by

$$
\widehat{M_{k t}}=\sum_{j} M_{j k 0}+\sum_{j} \frac{M_{j k 0}}{\sum_{k} M_{j k 0}}\left(\sum_{k} M_{j k t}-\sum_{k} M_{j k 0}\right) .
$$

The predicted share of immigrants in each district $\widehat{m_{k t}}$ is given by

$$
\widehat{m_{k t}}=\frac{\widehat{M_{k t}}}{N_{k t}+\widehat{M_{k t}}}
$$

where $N_{k t}$ is the stock of natives in period $t$.

The base year for our baseline analysis is 1971 and the censuses of 1981 and 1991 are used for examining the robustness of the results. The geographical units are districts, which are the second-level administrative division, after federal states. ${ }^{16} \mathrm{We}$ focus on the two main countries of origin, Turkey and former Yugoslavia, and group immigrants from other origin states into a residual category. Turks and persons from the former Yugoslavia were the two largest groups of immigrants, and they account for more than two-thirds of immigrants up to 2010.

The predicted percentage of immigrants in a district is used to instrument the share of immigrant employees in each firm (immigrant share ${ }_{i t}$ ). The exogeneity of the instrument requires that past economic or political shocks that affect unionization are not persistent and do not impact the current unionization behavior. This seems plausible

\footnotetext{
15 There is empirical evidence that immigrants tend to move to places where earlier immigrants from the same origin live. See, e.g., Bartel (1989), Bauer et al. (2007, 2009), Epstein (2008, 2010), Jaeger (2007), Munshi (2003), Rathelot and Safi (2014). This sort of instrument is widely used in the literature. For instance, for Austria, examples are Winter-Ebmer and Zweimüller (1996) and Winter-Ebmer and Zweimüller (1999), who use lags of the share of immigrants, and Halla et al. (2017) who use a similar Card-type instrument.

16 As there have been several administrative reforms since 1971, one district, Murtal, is excluded from the analysis, resulting in a total of 119 districts, including Viennese ones. Note that this number of districts is greater than 50, which is the number of clusters typically considered the lower limit for the use of this kind of correction (Angrist and Pischke 2008; Bertrand et al. 2004).
} 
since the base year and the period of analysis are separated by three decades. Also, as argued by Halla et al. (2017), the allocation of immigrants before 1971, inspired by international agreements with Turkey (1964), Yugoslavia (1966), and a system of quotas by region and sector, was not linked to political and labor market conditions. ${ }^{17}$ Between 1961 and 1971, the number of immigrants from Turkey (Yugoslavia) increased by a factor of 60 (20). To control for a potential correlation of their distribution over districts with the industrial composition, we include 44 industrial indicator variables in our analysis.

Figure 3 plots the correlation between union density and the proportion of immigrant employees in firms, both in levels and changes. There is a negative relationship between natives' union density and the share of immigrants in the firm in levels, but this is not evident when we consider year-on-year changes. Table 1 shows the main descriptive statistics of our sample. They reflect the overall decline in union membership rates. For example, for the sample of 2002-2007, roughly $18 \%$ of the employees in our sample were trade union members in 2002 and this rate declined to about $16 \%$. For the sample of 2007-2012, 15.6\% of native employees were trade union members in 2007 and by 2012 this dropped to around $15 \%$. A comparison of unionization rates for different demographic groups does not suggest that union membership declined more for a particular demographic group. However, the overall share of immigrant employees increased slightly in both samples, for the sample of 2002-2007, it increased from 17.4 to $19.9 \%$; in the sample of $2007-2012$, it increased from 20.3 to $23.2 \%$.

\section{Results}

We present our set of estimation results in Table 2. Column (I) presents results from an OLS regression. The main result is a small positive association between the change of the share of immigrant employees and the change of the unionization rate of native workers in a firm. ${ }^{18}$ Other significant coefficients are estimated for the initial share of females, the age composition in the firm, the average experience of employees in a firm, and the local unemployment rate. As discussed above, it is likely that these migration estimates are biased due to the endogeneity of immigrant employees in a firm.

The results from three different IV estimations are tabulated in columns (II)-(IV) of Table 2. In all IV-specifications, we use past distribution patterns of immigrants as the basis for estimating the predicted share of immigrants by district according to Card's (2001) shift-share approach. The specifications differ in the base period that is used for estimating the shift-share instrument. The specification in column (II) is estimated using data from the 1971 census, the specification in column (III) is based on data from the 1981 census, and the specification in column (IV) is based on data

\footnotetext{
17 Halla et al. (2017) argue that the immigrants' share in 1971 and the long-term political preferences of the population in a district, proxied by the previous election results of xenophobic parties, are not systematically linked - nor are the quota linked to labor market outcomes, such as unemployment rates or vacancies.

18 The regressions include industry and region fixed effects. A set of similar regressions where the dependent variable enumerates the change in the share of unionized employees among all employees in a firm is available on request; the results are very similar.
} 
from the 1991 census. Detailed results of the first stages are presented in Table 3. Overall, the choice of the base period does not change the estimated coefficients. The relevance of the instruments is formally shown by the Kleibergen-Paap $r k$ Wald $F$ statistic, which is robust to clustering (Kleibergen and Paap 2006). The specification presented in column (II), which uses a base period that was 30 years earlier, yields the greatest F-value of the three specifications.

In contrast to the OLS specification of column (I), the results from the IVspecifications all indicate a negative and relatively large impact of immigrants on the unionization rate of native employees in a firm. The other estimated coefficients differ only little from the OLS results. We estimate that a one percentage point increase in the share of immigrant employees in a firm results in a 0.5 to 0.65 percentage point reduction in the unionization rate of native employees. Both reverse causation and omitted variables bias could explain the difference in the OLS results. Unionization in a firm could lead to a larger share of immigrants in the firm, i.e., reverse causality, if firms hire more immigrants to weaken the union. Similarly, firms in old industries are typically more unionized than firms in new sectors. If immigrant employees have skills that are demanded more in older than in new industries, immigrant employees will work more in unionized firms due to the relative demand for their skills. Alternatively, omitted variables could also lead to bias if, for example, in badly performing firms both unionization rates and the demand for immigrant employees are lower than in more successful firms.

In "Appendix," Table 8 we show results from several robustness checks. First, we show results which are based on the changes of the covariates, rather than their levels. Secondly, we exclude observations from certain districts where a specific unemployment benefit policy for unemployed the steel workers led to long benefit durations (Winter-Ebmer 2003). In columns (II) and (III), we present results when we exclude these districts and the steel industry. Finally, we present results that show the sensitivity of the estimated effects on the time intervals chosen. In columns (IV) and (V), we use the changes over 3-year and over 7-year intervals, instead of over five years as in our main results. All these robustness checks confirm the results shown above.

\subsection{Subgroups}

To analyze our results in more detail, we estimate our specifications using several subsamples. These results are tabulated in Table $4 .{ }^{19}$ In the first two columns, we present the estimated coefficients separately for men and women. The estimated coefficient for men is smaller than those of the main results (it is larger in absolute numbers). The coefficient for women is not statistically significant from zero at conventional levels. It seems that men react more strongly to the presence of immigrant employees in firms than women do. The stronger response of men is consistent with prior evidence that men in Austria, but not women, face negative employment effects from immigration (Winter-Ebmer and Zweimüller 1999).

\footnotetext{
19 The results from specifications with the shift-share instruments based on 1981 or 1991 are remarkably similar to the ones reported here and therefore omitted for brevity. We also obtain similar results when we use a firm's workforce for the calculation of rates.
} 
We also examine the sensitivity of our results if we stratify the sample by age. We estimate the specifications separately for different age groups, 16-29, 30-44, and 45-64 years of age. The results presented in columns (V)-(VII) of Table 4 indicate that the negative impact is strongest for older employees; the estimated effects for prime-age and young employees are also negative and of the same magnitude. Older employees could face more negative employment effects due to immigration than younger employees [Glitz (2012), Bonin (2005) or Foged and Peri (2016)] and leave firms more often, perhaps choosing to retire early. ${ }^{20}$

In columns (III) and (IV) of Table 4, we present the results for blue-collar and whitecollar employees. Whereas the results for white-collar employees are almost identical to our main results above, the estimated results for blue-collar employees are about the same size, but are not statistically significant. The reason for these differences is that for this subgroup the instrument is not relevant, the F-statistic is only around 2, while for white-collar workers it is about 53. The instrument relies on predicted shares of immigrants from Turkey and former Yugoslavia in 1971. The share of blue-collar workers who were from Turkey and former Yugoslavia declined from 95\% in 1972 to $61 \%$ in 2017. In contrast, for white-collar workers this share increased from $15 \%$ in 1971 to $38 \%$ in 2017. (Put differently, the share of immigrant employees from other countries (Hungary, Czech Republic, Slovak Republic, and Poland) increased among blue-collar employees.) The predictive value of the instrument for blue-collar jobs is thus rather poor and we are hesitant to draw any conclusions from this particular result. Additional results in Table 12 in the "Appendix" show that results are identified in firms having both white-collar and blue-collar workers; while effects for blue-collar workers in those firms are quantitatively similar, they are statistically insignificant.

\subsection{Potential channels}

The negative impact of immigrant employees on unionization could be caused by firms substituting away from unionized natives to other employees. In this case, we expect to observe an increase in the separation rate of unionized native employees and, possibly, a lower probability of hiring unionized employees (or fewer employees joining the union after a job move).

In Table 5, we present evidence for these possible channels. All estimates use the same instrumental variables strategy as before. We first investigate the effect of immigrant workers on native stayers, unionized (column I) and non-unionized (column II). We do this by estimating the impact of immigrant employees on the share of unionized employees who were employed by the firm in the first and the last period in our sample. In other words, to examine the extent of employees quitting the union, we restrict the calculation of the dependent variable to employees who were with the firm over a longer period. These estimates do not provide sufficient evidence to conclude that immigrants have an impact on the share of native stayers.

\footnotetext{
20 Table 10 in "Appendix" shows that results are similar for the service and manufacturing sector, but not statistically significant for the latter. The results in Table 11 show insignificant results for firms below firm size 50, they are negative and statistically significant for firms with more than 50 employees.
} 
The results in columns (I) and (II) indicate no effect of immigrant employees on union members' terminating their membership. In columns (III) to (V) of Table 5, we present estimation results of the impact on separations and in columns (VI) to (VIII) on hiring of native employees.

The results from these estimations indicate that there is, indeed, a change in the workforce away from native employees. We find that increased employment of immigrant workers increases the separation rate and reduces the hiring rate of native employees significantly.

The case for unionized native workers is more subtle: while we do see an increase in the separation rate of unionized native workers (III), there is no significant corresponding effect for hiring (VI). Note, that the estimated effects presented in Table 5 cannot directly be compared between non-unionized and unionized workers. As the share of unionized workers is only around 0.23 , the separation rate per unionized native worker in column (IV) should be multiplied by four to make it comparable with column (V): migration does lead to more separations, and even more separations of unionized native workers. In contrast to this, the presence of more migrants reduces hiring of non-unionized native workers, but has no effect on hirings of unionized workers.

The largest impact on unionized native employees is through separations and we aim to see whether separations were voluntary or involuntary. Unfortunately, there is no direct indicator for whether a separation was voluntary or involuntary in our data. We, however, have information on the receipt of unemployment benefits and use the start of benefit receipt as an indicator for the type of separation. In Austria, employees who quit voluntarily are not entitled to unemployment benefits for the first 28 days after separation. We define a separation as involuntary if an employee receives unemployment benefits in the 28 days immediately after the separation. We classify all separations where employees are below the statutory pension age (60 for women and 65 for men) and who receive an old-age pension or a disability pension after leaving their job as early retirement.

These estimation results are tabulated in Table 6 . The estimates suggest that the changes in the firms' workforce are not the result of more involuntary separations of native unionized employees as the estimated coefficient is not different from zero (column (I)). However, more immigrant employees led to more early retirement as well as to other separations (including voluntary ones). These results do not suggest that separations were induced by employers but rather sought by employees. ${ }^{21}$

In contrast to e.g., Finseraas et al. (2020), Brady (2007) or Burgoon et al. (2010) who do not find negative effects of immigration on union density, our results suggest that the impact of immigrant employees on union membership is more nuanced. We find evidence that more immigrant employees lower native employees' union membership rates, especially that of men. The effect appears to be stronger for older employees who appear to quit their previous jobs, either voluntarily or for early retirement.

\footnotetext{
21 See also Bryson et al. (2005), who suggest that changes in union status in the United Kingdom are often linked to job movements. Similarly, Jódar et al. (2011) report that the main reason for quitting union membership in Spain is retirement or incapacity to work. For a survey of the factors leading to employees leaving trade unions, see Dobbie and Nahm (2018) or Leschke and Vandaele (2018).
} 


\section{Conclusions}

Trade unions differ in their approaches to immigrant employees (Wrench 2004), which might determine their success in recruiting employees. In Austria the number of immigrant employees increased strongly and trade union membership declined sharply over the past decades. We analyze whether, ceteris paribus, immigrant inflows might have contributed to the decline in union membership rates of native employees or not.

We use an instrumental variables approach and find a negative impact of the number of immigrants in a firm on the native employees' union membership rates. Our analyses indicate that the negative correlation between immigrant employees and trade union membership of native employees is not caused by native employees quitting their unions. In contrast, the results suggest that the lower membership rates are caused by native union members leaving their firms. ${ }^{22}$ Separations of middle-aged or older union members have increased after the hiring of immigrant employees. Moreover, these separations are predominantly in the form of early retirement. These separations might have arisen because of reduced job satisfaction of native union members but also due to other changes in workplace relations coming about with an increasing internationalization of the workplace. Some counter-acting effects stem from a reduced hiring of non-unionized native workers.

Based on our estimation results, immigration accounts for a 2.8 percentage points decrease in union density among native employees, so the impact of immigration on unionization rates of native workers within firms can explain approximately half of the decline in union density over 2002-2012 in private-sector firms. Penninx and Roosblad (2000) stress that trade unions face three dilemmas when confronted with a sizable number of immigrant employees, whether to oppose or to cooperate with the recruitment of immigrants; whether to recruit them as regular members or to offer separate forms of affiliation short of full membership; and whether or not they should undertake special measures to support immigrants in the labor market. To a large extent, these dilemmas continue being valid (Marino et al. 2015). Our results show that union members do not leave their union in the case of a stronger presence of immigrant employees in their firm, but some employees quit the firm or opt for early retirement.

Funding Open access funding provided by Johannes Kepler University Linz

\section{Declarations}

Conflict of interest The authors have no relevant financial or non-financial interests to disclose.

Open Access This article is licensed under a Creative Commons Attribution 4.0 International License, which permits use, sharing, adaptation, distribution and reproduction in any medium or format, as long as you give appropriate credit to the original author(s) and the source, provide a link to the Creative Commons licence, and indicate if changes were made. The images or other third party material in this article are included in the article's Creative Commons licence, unless indicated otherwise in a credit line to the material. If material is not included in the article's Creative Commons licence and your intended use is not permitted

\footnotetext{
22 Figure 4 in "Appendix" shows transitions of unionized and non-unionized workers to other firms with respect to the share of foreign workers in the firm with some increase towards non-unionized other firms.
} 
by statutory regulation or exceeds the permitted use, you will need to obtain permission directly from the copyright holder. To view a copy of this licence, visit http://creativecommons.org/licenses/by/4.0/.

\section{Appendix}

See Fig. 4 and Tables 7, 8, 9, 10, 11, 12.
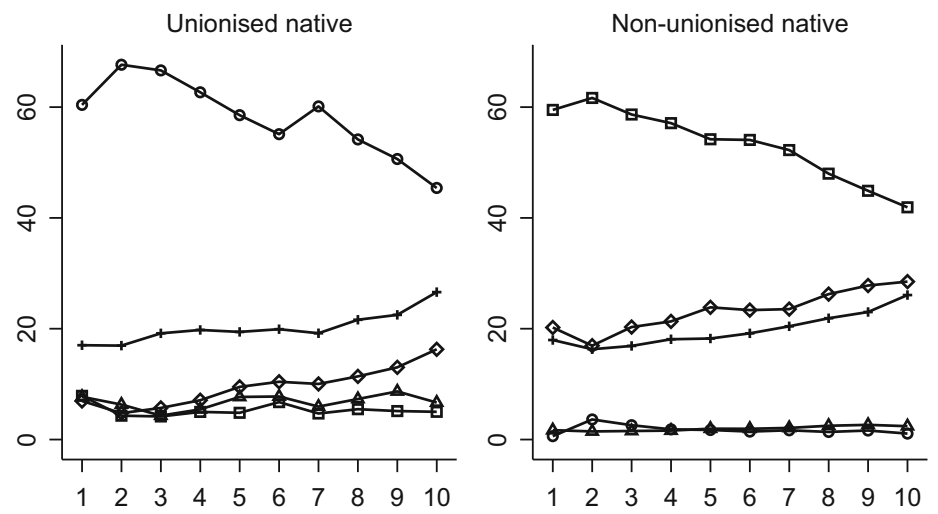

ำ

Unionised foreigner
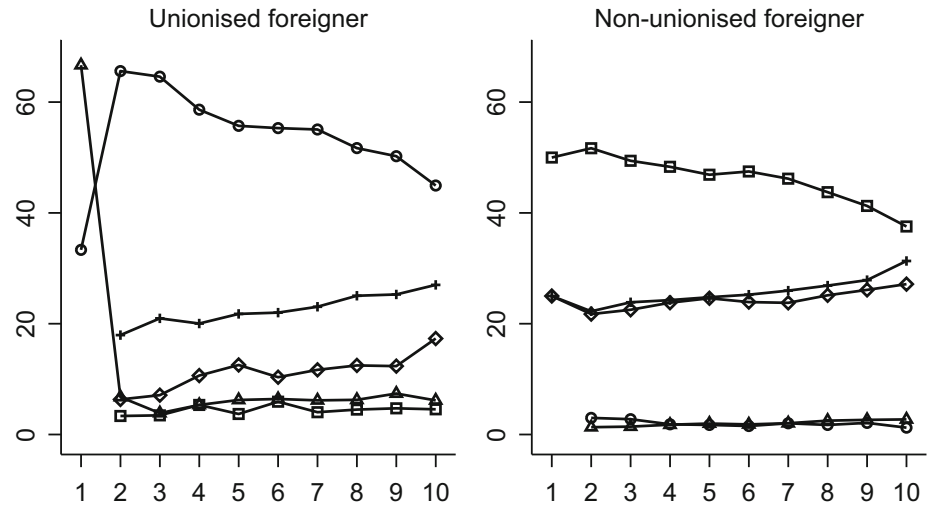

Decile of share of foreign workers
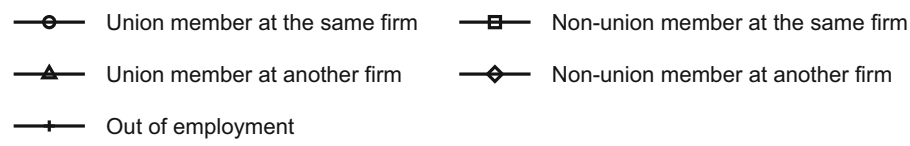

Non-union member at another firm

Fig. 4 Transition rates of worker types, by share of immigrant employees in their firm (2002-2007, 20072012). Source: Authors' analysis from ASSD. Each diagram shows the changes in the transition rates of a group of employee between (2002-2007 and 2007-2012), by the decile of the share of immigrant employees in their firm 
Table 7 Comparison between the estimating sample and observations not used. Source: Authors' analysis from ASSD

\begin{tabular}{|c|c|c|c|c|c|c|}
\hline & \multicolumn{2}{|l|}{2002} & \multicolumn{2}{|l|}{2007} & \multicolumn{2}{|l|}{2012} \\
\hline & Sample & Out of sample & Sample & Out of sample & Sample & Out of sample \\
\hline \multicolumn{7}{|l|}{ Worker's characteristics } \\
\hline Union member & 0.244 & 0.138 & 0.207 & 0.098 & 0.184 & 0.073 \\
\hline Immigrant & 0.164 & 0.178 & 0.186 & 0.219 & 0.215 & 0.248 \\
\hline Age & 37.146 & 37.193 & 38.113 & 38.115 & 38.912 & 38.885 \\
\hline White-collar & 0.515 & 0.530 & 0.524 & 0.527 & 0.530 & 0.558 \\
\hline Years of experience & 15.604 & 14.500 & 16.685 & 15.274 & 17.351 & 15.786 \\
\hline Years of tenure & 6.551 & 4.869 & 6.308 & 4.663 & 6.929 & 4.569 \\
\hline \multicolumn{7}{|l|}{ Firm's characteristics } \\
\hline Firm union density & 0.243 & 0.137 & 0.207 & 0.098 & 0.184 & 0.073 \\
\hline 50 workers or less & 0.351 & 0.678 & 0.333 & 0.701 & 0.334 & 0.722 \\
\hline 51-100 workers & 0.132 & 0.076 & 0.126 & 0.071 & 0.130 & 0.058 \\
\hline $101-250$ workers & 0.185 & 0.098 & 0.183 & 0.089 & 0.184 & 0.081 \\
\hline More than 250 workers & 0.332 & 0.147 & 0.358 & 0.139 & 0.351 & 0.139 \\
\hline Proportion of females & 0.357 & 0.433 & 0.362 & 0.435 & 0.368 & 0.457 \\
\hline Proportion of white-collars & 0.515 & 0.530 & 0.524 & 0.527 & 0.530 & 0.558 \\
\hline Average age & 37.146 & 37.193 & 38.113 & 38.115 & 38.912 & 38.885 \\
\hline Average experience & 15.604 & 14.500 & 16.685 & 15.274 & 17.351 & 15.786 \\
\hline Average tenure & 6.550 & 4.868 & 6.307 & 4.662 & 6.929 & 4.568 \\
\hline Proportion of foreigners & 0.164 & 0.178 & 0.186 & 0.219 & 0.215 & 0.248 \\
\hline Mining and quarrying & 0.003 & 0.011 & 0.008 & 0.003 & 0.008 & 0.002 \\
\hline Manufacturing & 0.354 & 0.217 & 0.317 & 0.194 & 0.296 & 0.154 \\
\hline $\begin{array}{l}\text { Electricity, gas and water } \\
\text { supply }\end{array}$ & 0.017 & 0.007 & 0.015 & 0.004 & 0.012 & 0.005 \\
\hline Construction & 0.105 & 0.110 & 0.099 & 0.118 & 0.101 & 0.110 \\
\hline $\begin{array}{l}\text { Wholesale and retail trade; } \\
\text { repairs }\end{array}$ & 0.218 & 0.256 & 0.227 & 0.251 & 0.235 & 0.255 \\
\hline Hotels and restaurants & 0.054 & 0.114 & 0.059 & 0.122 & 0.063 & 0.129 \\
\hline $\begin{array}{l}\text { Transport, storage and } \\
\text { communication }\end{array}$ & 0.076 & 0.071 & 0.080 & 0.071 & 0.085 & 0.073 \\
\hline Financial intermediation & 0.069 & 0.031 & 0.066 & 0.023 & 0.059 & 0.028 \\
\hline $\begin{array}{l}\text { Real estate, renting and } \\
\text { business activities }\end{array}$ & 0.104 & 0.181 & 0.128 & 0.213 & 0.141 & 0.244 \\
\hline Burgenland & 0.022 & 0.028 & 0.022 & 0.029 & 0.023 & 0.028 \\
\hline Carinthia & 0.062 & 0.057 & 0.061 & 0.060 & 0.062 & 0.051 \\
\hline Lower Austria & 0.159 & 0.165 & 0.177 & 0.157 & 0.184 & 0.143 \\
\hline Upper Austria & 0.211 & 0.150 & 0.210 & 0.167 & 0.212 & 0.153 \\
\hline Salzburg & 0.081 & 0.077 & 0.080 & 0.082 & 0.085 & 0.091 \\
\hline
\end{tabular}


Table 7 continued

\begin{tabular}{|c|c|c|c|c|c|c|}
\hline & \multicolumn{2}{|l|}{2002} & \multicolumn{2}{|l|}{2007} & \multicolumn{2}{|l|}{2012} \\
\hline & Sample & Out of sample & Sample & Out of sample & Sample & Out of sample \\
\hline Styria & 0.119 & 0.111 & 0.118 & 0.103 & 0.118 & 0.102 \\
\hline Tyrol & 0.100 & 0.083 & 0.098 & 0.085 & 0.101 & 0.083 \\
\hline Vorarlberg & 0.052 & 0.036 & 0.048 & 0.037 & 0.027 & 0.032 \\
\hline Vienna & 0.194 & 0.295 & 0.185 & 0.280 & 0.189 & 0.318 \\
\hline [1em] No. of observations & \multicolumn{2}{|c|}{$1,091,329698,299$} & \multicolumn{2}{|c|}{$1,259,053658,389$} & \multicolumn{2}{|c|}{$1,275,857472,148$} \\
\hline
\end{tabular}

The table details the descriptive statistics for the estimating sample and the observations not used for estimation. Firms in sectors NACE code 10-74 only. The sample is restricted to firms which are observed in each year 2002-2012 and that have 10 or more employees in any year between 2002 and 2012. Not selected observations are from firms with fewer than 10 employees or those that are not present in each year 2002-2012. Number of observations are firm $\times$ year

Table 8 Robustness checks of the effects of the share of immigrant employees on the share of unionized natives in Austria. Source: Authors' analysis from ASSD

\begin{tabular}{lllll} 
(I) & (II) & (III) & (IV) & (V) \\
\hline $\begin{array}{l}\text { Covariates in } \\
\text { changes }\end{array}$ & $\begin{array}{c}\text { Styria } \\
\text { excluded }\end{array}$ & $\begin{array}{c}\text { Steel } \\
(271-273) \\
\text { excluded }\end{array}$ & $\begin{array}{c}\text { 3-year } \\
\text { intervals }\end{array}$ & $\begin{array}{c}\text { 7-year } \\
\text { intervals }\end{array}$ \\
\hline
\end{tabular}

\section{Panel A. 2SLS estimates}

Change in the share of

$\begin{array}{lllll}-0.761 * * * & -0.432 * * * & -0.428 * * * & -0.789 * * * & -0.630 * * * \\ (0.262) & (0.160) & (0.159) & (0.262) & (0.171)\end{array}$

Panel B. First-stage estimates

\begin{tabular}{|c|c|c|c|c|c|}
\hline \multirow{2}{*}{$\begin{array}{l}\text { Change in the pre- } \\
\text { dicted share of for- } \\
\text { eigners in the dis- } \\
\text { trict }\end{array}$} & $0.306^{* * *}$ & $0.380 * *$ & $0.378 * * *$ & $0.292 * * *$ & $0.398 * * *$ \\
\hline & $(0.053)$ & $(0.048)$ & $(0.050)$ & $(0.041)$ & $(0.060)$ \\
\hline Wald $F$-statistic (1st stage) & 33.299 & 43.603 & 44.805 & 50.787 & 44.593 \\
\hline $\begin{array}{l}\text { Mean of the dependent } \\
\text { variable }\end{array}$ & 0.217 & 0.209 & 0.206 & 0.245 & 0.232 \\
\hline $\begin{array}{l}\text { Mean of the independent } \\
\text { variable }\end{array}$ & 0.141 & 0.149 & 0.143 & 0.124 & 0.140 \\
\hline No. of observations & 59,732 & 52,728 & 52,653 & 132,872 & 46,770 \\
\hline
\end{tabular}

*** Significant at $1 \%$ level; ** significant at $5 \%$ level; * significant at $10 \%$ level. Results from IV-estimates where the instrument is based on Census 1971 data. Standard errors clustered at the district level in parentheses. All specifications include the initial share of female natives, the initial share of white-collar natives, the initial share of natives aged 16-29 and 45-64, the initial district-level unemployment rate, a time-dummy for the period 2007-2012, industry and region fixed effects and an intercept. All regressions are weighted by the number of native employees at the beginning of the period. 3-year and 7-year intervals comprise 2000-2003, 2003-2006, 2006-2009 and 2009-2012 and 1998-2005 and 2005-2012, respectively 
Table 9 Job changes and union membership transitions, 2002-2007 and 2007-2012. Source: Authors' analysis from ASSD

\begin{tabular}{|c|c|c|c|c|c|c|}
\hline & $\begin{array}{l}\text { Union member } \\
\text { at the same } \\
\text { firm }\end{array}$ & $\begin{array}{l}\text { r Non-union } \\
\text { member at } \\
\text { the same } \\
\text { firm }\end{array}$ & $\begin{array}{l}\text { Union } \\
\text { member at } \\
\text { another firm }\end{array}$ & $\begin{array}{l}\text { Non-union } \\
\text { member at } \\
\text { another firm }\end{array}$ & $\begin{array}{l}\text { Out of } \\
\text { employment }\end{array}$ & Total \\
\hline Unionized native & $\begin{array}{l}61.61 \\
(274,175)\end{array}$ & $\begin{array}{l}4.96 \\
(22,091)\end{array}$ & $\begin{array}{l}6.35 \\
(28,248)\end{array}$ & $\begin{array}{l}7.87 \\
(35,027)\end{array}$ & $\begin{array}{l}19.21 \\
(85,497)\end{array}$ & $\begin{array}{l}100.00 \\
(445,038)\end{array}$ \\
\hline $\begin{array}{l}\text { Non-unionized } \\
\text { native }\end{array}$ & $\begin{array}{l}1.71 \\
(25,462)\end{array}$ & $\begin{array}{l}54.13 \\
(805,620)\end{array}$ & $\begin{array}{l}1.95 \\
(28,987)\end{array}$ & $\begin{array}{l}22.84 \\
(339,891)\end{array}$ & $\begin{array}{l}19.38 \\
(288,480)\end{array}$ & $\begin{array}{l}100.00 \\
(1,488,440)\end{array}$ \\
\hline $\begin{array}{l}\text { Unionized } \\
\text { immigrant }\end{array}$ & $\begin{array}{l}50.77 \\
(40,866)\end{array}$ & $\begin{array}{l}4.55 \\
(3664)\end{array}$ & $\begin{array}{l}6.40 \\
(5149)\end{array}$ & $\begin{array}{l}13.52 \\
(10,883)\end{array}$ & $\begin{array}{l}24.77 \\
(19,937)\end{array}$ & $\begin{array}{l}100.00 \\
(80,499)\end{array}$ \\
\hline $\begin{array}{l}\text { Non-unionized } \\
\text { immigrant }\end{array}$ & $\begin{array}{l}1.68 \\
(5529)\end{array}$ & $\begin{array}{l}41.94 \\
(137,780)\end{array}$ & $\begin{array}{l}2.44 \\
(8030)\end{array}$ & $\begin{array}{l}25.71 \\
(84,455)\end{array}$ & $\begin{array}{l}28.22 \\
(92,706)\end{array}$ & $\begin{array}{l}100.00 \\
(328,500)\end{array}$ \\
\hline Total & $\begin{array}{l}14.77 \\
(346,032)\end{array}$ & $\begin{array}{l}41.37 \\
(969,155)\end{array}$ & $\begin{array}{l}3.01 \\
(70,414)\end{array}$ & $\begin{array}{l}20.08 \\
(470,256)\end{array}$ & $\begin{array}{l}20.77 \\
(486,620)\end{array}$ & $\begin{array}{l}100.00 \\
(2,342,477)\end{array}$ \\
\hline
\end{tabular}

Transitions from 2002 (2007) to 2007 (2012) for all workers employed in 2002 and 2007 in the firms of the sample of interest. Each row gives the average share of transitions from 2002 to 2007, and from 2007 to 2012, to the stated destination. For example, $62.43 \%$ of unionized natives employees of 2002 and 2007 were unionized native employees with the same firm in 2007 and 2012. The number of workers is shown between parentheses

Table 10 Effects of the share of immigrant employees on the share of unionized natives in Austria, regression in changes, 2002-2007 and 2007-2012, results by sector of activity. Source: Authors' analysis from ASSD

\begin{tabular}{lll}
\hline & (I) & (II) \\
& Manufacturing and construction & Services \\
\hline $\begin{array}{l}\text { Panel A. 2SLS estimates } \\
\text { Change in the share of foreign workers }\end{array}$ & -0.496 & $-0.470^{* * * *}$ \\
& $(1.057)$ & $(0.141)$ \\
$\begin{array}{l}\text { Panel B. First-stage estimates } \\
\text { Change in the pre- }\end{array}$ & $0.194^{* *}$ & $0.437^{* * *}$ \\
$\begin{array}{l}\text { dicted share of for- } \\
\text { eigners in the dis- } \\
\text { trict }\end{array}$ & & \\
& $(0.083)$ & \\
Wald F-statistic (1st stage) & 5.518 & $0.071)$ \\
Mean of the dependent variable & 0.324 & 37.439 \\
Mean of the independent variable & 0.142 & 0.128 \\
No. of observations & 22,089 & 0.141 \\
\hline
\end{tabular}

*** Significant at $1 \%$ level; ${ }^{* *}$ significant at $5 \%$ level; * significant at $10 \%$ level. Results from IV-estimates where the instrument is based on Census 1971 data. Standard errors clustered at the district level in parentheses. All specifications include the initial share of female natives, the initial share of white-collar natives, the initial share of natives aged 16-29 and 45-64, the initial district-level unemployment rate, a time-dummy for the period 2007-2012, industry and region fixed effects and an intercept. All regressions are weighted by the number of native employees at the beginning of the period 
Table 11 Effects of the share of immigrant employees on the share of unionized natives in Austria, regression in changes, 2002-2007 and 2007-2012, results by firm size. Source: Authors' analysis from ASSD

$\begin{array}{lll}\text { (I) } & \text { (II) } & \text { (III) } \\ 10 \leq \text { Firm size }<25 & 25 \leq \text { Firm size }<50 & \text { Firm size } \geq 50\end{array}$

Panel A. 2SLS estimates

Change in the share of foreign workers $\quad-0.036$ $-0.835 \quad-0.562 * *$

$(0.085)$

Panel B. First-stage estimates

Change in the pre-

$0.310^{* * * *} \quad 0.175^{*} \quad 0.410^{* * *}$

dicted share of for-

eigners in the dis-

trict

$(0.063) \quad(0.104)$

Wald $F$-statistic (1st stage)

Mean of the dependent variable

0.028

0.067

0.290

Mean of the independent variable

0.129

0.148

0.143

No. of observations

35,447

12,530

11,756

*** Significant at $1 \%$ level; ${ }^{* *}$ significant at $5 \%$ level; ${ }^{*}$ significant at $10 \%$ level. Results from IV-estimates where the instrument is based on Census 1971 data. Standard errors clustered at the district level in parentheses. All specifications include the initial share of female natives, the initial share of white-collar natives, the initial share of natives aged 16-29 and 45-64, the initial district-level unemployment rate, a time-dummy for the period 2007-2012, industry and region fixed effects and an intercept. All regressions are weighted by the number of native employees at the beginning of the period 
Table 12 Effects of the share of immigrant employees on the share of unionized natives in Austria, regression in changes, 2002-2007 and 2007-2012, results by groups. Source: Authors' analysis from ASSD

\begin{tabular}{|c|c|c|c|c|c|}
\hline & $\begin{array}{l}\text { (I) } \\
\text { Firms } \\
\text { with only } \\
\text { blue-collar } \\
\text { natives }\end{array}$ & $\begin{array}{l}\text { (II) } \\
\text { Firms } \\
\text { with only } \\
\text { white- } \\
\text { collar } \\
\text { natives }\end{array}$ & $\begin{array}{l}\text { (III) } \\
\text { Firms with } \\
\text { blue-collar } \\
\text { and white- } \\
\text { collar } \\
\text { natives }\end{array}$ & $\begin{array}{l}\text { (IV) } \\
\text { Firms with } \\
\text { blue-collar } \\
\text { and white- } \\
\text { collar } \\
\text { natives } \\
\text { (impact on } \\
\text { blue-collar } \\
\text { natives) }\end{array}$ & $\begin{array}{l}\text { (V) } \\
\text { Firms with } \\
\text { blue-collar } \\
\text { and white- } \\
\text { collar } \\
\text { natives } \\
\text { (impact on } \\
\text { white- col- } \\
\text { lar natives) }\end{array}$ \\
\hline \multicolumn{6}{|l|}{ Panel A. 2SLS estimates } \\
\hline Change in share of foreign workers & $\begin{array}{l}-0.114 \\
(0.686)\end{array}$ & $\begin{array}{l}-0.524 * * * \\
(0.156)\end{array}$ & $\begin{array}{l}-0.755^{* *} \\
(0.310)\end{array}$ & $\begin{array}{l}-0.775 \\
(0.929)\end{array}$ & $\begin{array}{l}-0.551 * * \\
(0.214)\end{array}$ \\
\hline \multicolumn{6}{|l|}{ Panel B. First-stage estimates } \\
\hline \multirow[t]{2}{*}{$\begin{array}{l}\text { Change in the pre- } \\
\text { dicted share of for- } \\
\text { eigners in the dis- } \\
\text { trict }\end{array}$} & $-0.339 * *$ & $0.465 * * *$ & $0.336 * * *$ & $0.151^{*}$ & $0.446 * * *$ \\
\hline & $(0.172)$ & $(0.062)$ & $(0.053)$ & $(0.080)$ & $(0.066)$ \\
\hline Wald $F$-statistic (1st stage) & 3.869 & 55.851 & 40.992 & 3.593 & 46.267 \\
\hline Mean of the dependent variable & 0.233 & 0.113 & 0.238 & 0.307 & 0.174 \\
\hline Mean of the independent variable & 0.215 & 0.103 & 0.148 & 0.162 & 0.134 \\
\hline No. of observations & 4833 & 14,648 & 40,252 & 37,910 & 38,994 \\
\hline No. of firms & 3676 & 9993 & 25,581 & 23,967 & 24,708 \\
\hline
\end{tabular}

*** Significant at $1 \%$ level; ${ }^{* *}$ significant at $5 \%$ level; ${ }^{*}$ significant at $10 \%$ level. Results from IV-estimates where the instrument is based on Census 1971 data. Standard errors clustered at the district level in parentheses. All specifications include the initial share of female natives, the initial share of white-collar natives, the initial share of natives aged 16-29 and 45-64, the initial district-level unemployment rate, a time-dummy for the period 2007-2012, industry and region fixed effects and an intercept. All regressions are weighted by the number of native employees of each category at the beginning of the period

\section{References}

Abowd JM, Freeman RB (1991) Immigration, trade and the labor market. University of Chicago Press, Chicago

Afonso A, Devitt C (2016) Comparative political economy and international migration. Soc Econ Rev 14(3):591-613

Agell J (1999) On the benefits from rigid labour markets: norms, market failures, and social insurance. Econ J 109(453):143-164

Agell J (2002) On the determinants of labour market institutions: rent seeking vs. social insurance. German Econ Rev 3(2):107-135

Aiginger K, Guger A (2005) The European socioeconomic model, WIFO working paper 266, Austrian Institute of Economic Research

Alesina A, Baqir R, Easterly W (1999) Public goods and ethnic divisions. Quart J Econ 114(4):1243-1284 Alesina A, Miano A, Stantcheva S (2018) Immigration and redistribution, NBER Working Paper Series 24733, National Bureau of Economic Research

Alesina A, Murard E, Rapoport H (2019) Immigration and preferences for redistribution in Europe, NBER Working Paper Series 25562, National Bureau of Economic Research 
Alho R (2013) Trade union responses to labour immigrants: selective solidarity. Finnish Yearbook Popul Res 48:77-102

Altonji JJ, Card D (1991) The effects of immigration on the labor market outcomes of less-skilled natives. In: Abowd JM, Freeman RB (eds) Immigration, trade, and the labor market. University of Chicago Press, Chicago, pp 201-234

Angrist JD, Pischke J-S (2008) Mostly harmless econometrics: an empiricist's companion. Princeton University Press, Princeton

Autor DH, Dorn D, Hanson GH (2013) The China syndrome: local labor market effects of import competition in the United States. Am Econ Rev 103(6):2121-2168

Autor DH, Dorn D, Hanson GH, Song J (2014) Trade adjustment: worker-level evidence. Quart J Econ 129(4):1799-1860

Balsvik R, Jensen S, Salvanes KG (2015) Made in China, sold in Norway: local labor market effects of an import shock. J Public Econ 127:137-144

Bartel AP (1989) Where do the new US immigrants live? J Law Econ 7(4):371-391

Bauer T, Epstein G, Gang IN et al (2007) The influence of stocks and flows on migrants' location choices. Res Labor Econ 26:199-229

Bauer T, Epstein GS, Gang IN (2009) Measuring ethnic linkages among migrants. Int J Manpow 30(1/2):5669

Bertrand M, Duflo E, Mullainathan S (2004) How much should we trust differences-in-differences estimates? Quart J Econ 119(1):249-275

Bonin H (2005) Wage and employment effects of immigration to Germany: evidence from a skill group approach, IZA discussion paper 1875

Bound J, Brown C, Mathiowetz N (2001) Measurement error in survey data. In: Heckman JJ, Leamer E (eds) Handbook of econometrics, vol 5. North Holland, Amsterdam, pp 3705-3843

Brady D (2007) Institutional, economic, or solidaristic? Assessing explanations for unionization across affluent democracies, work and occupations 34(1):67-101

Bryson A, Ebbinghaus B, Visser J (2011) Introduction: causes, consequences and cures of union decline. Eur J Ind Relat 17(2):97-105

Bryson A, Gómez R, Gunderson M, Meltz N (2005) Youth-adult differences in demand for unionization: are American, British and Canadian workers all that different. J Lab Res 26(1):155-167

Burgoon B, Fine J, Jacoby W, Tichenor D (2010) Immigration and the transformation of American unionism. Int Migr Rev 44(4):933-973

Card D (2001) Immigrant inflows, native outflows, and the local market impacts of higher immigration. J Law Econ 19(1):22-64

Card D (2009) Immigration and inequality. Am Econ Rev 99(2):1-21

Chesher A, Rosen AM (2017) Generalized instrumental variable models. Econometrica 85(3):959-989

Dauth W, Findeisen S, Suedekum J (2014) The rise of the East and the Far East: German labor markets and trade integration. J Eur Econ Assoc 12(6):1643-1675

Defreitas G (1993) Unionization among racial and ethnic minorities. Ind Labor Relat Rev 46(2):284-301

Dobbie M, Nahm D (2018) The determinants of individual union membership in Australia: a structural approach using panel data. Econ Pap 37(1):75-91

Dreher A, Gaston N (2007) Has globalisation really had no effect on unions? Kyklos 60(2):165-186

Dunlop JT (1958) Industrial relations systems. Henry Holt and Co, New York

Epstein GS (2008) Herd and network effects in migration decision-making. J Ethn Migr Stud 34(4):567-583

Epstein GS (2010) Informational cascades and the decision to migrate. In: Epstein GS, Gang IN (eds) Migration and culture: frontiers of economic and globalization. Emerald Group Publishing, Bingley, pp 25-44

Facchini G, Mayda AM, Murard E (2016) Does immigration affect preferences for redistribution? Evidence across countries. In: Freeman GP, Mirilovic N (eds) Handbook on migration and social policy. Edward, Cheltenham, pp 293-314

Farber HS, Herbst D, Kuziemko I, Naidu S (2021) Unions and inequality over the twentieth century: new evidence from survey data. Quart J Econ 136(3):1325-1385

Ferguson J-P (2016) Racial diversity and union organizing in the United States, 1999-2008. Int Labor Relat Rev 69(1):53-83

Finseraas H (2008) Immigration and preferences for redistribution: an empirical analysis of European survey data. Comp Eur Polit 6(4):407-431 
Finseraas H (2009) Income inequality and demand for redistribution: a multilevel analysis of European public opinion. Scand Polit Stud 32(1):94-119

Finseraas H, Røed M, Schøne P (2020) Labour immigration and union strength. Eur Union Polit 21(1):3-23

Foged M, Peri G (2016) Immigrants' effect on native workers: new analysis on longitudinal data. Am Econ J Appl Econ 8(2):1-34

Frandsen B (2020) The surprising impacts of unionization: evidence from matched employer-employee data. J Law Econ 39(4):861-894

Gächter A (1995) Forced complementarity: the attempt to protect native Austrian workers from immigrants. J Ethn Migr Stud 21(3):379-398

Gächter A (2000) Austria: protecting indigenous workers from immigrants. In: Penninx R, Roosblad J (eds) Trade unions, immigration, and immigrants in Europe, 1960-1993, vol 1. Berghahn Books, New York, pp 65-90

Gächter G (2017) Trade unions and migration in Austria, 1993-2015. In: Marino S, Roosblad J, Penninx $\mathrm{R}$ (eds) Trade unions and migrant workers. Edward Elgar, Broadheath, pp 117-137

Glitz A (2012) The labor market impact of immigration: a quasi-experiment exploiting immigrant location rules in Germany. J Law Econ 30(1):175-213

Gorodzeisky A, Richards A (2013) Trade unions and migrant workers in Western Europe. Eur J Ind Relat 19(3):239-254

Gorodzeisky A, Richards A (2020) Do immigrants trust trade unions? A study of 18 European countries. Br J Ind Relat 58(1):3-26

Griliches Z, Hausman JA (1986) Error in variables in panel data. J Econom 31(1):93-118

Halla M, Wagner A, Zweimüller J (2017) Immigration and voting for the extreme right. J Eur Econ Assoc 6(1):1341-1385

Jaeger DA (2007) Green cards and the location choices of immigrants in the United States, 1971-2000. Res Labor Econ 27:131-183

Jaeger DA, Ruist J, Stuhler J (2018) Shift-share instruments and the impact of immigration, NBER working paper 24285

Jódar P, Alós R, Vidal S (2011) Why do workers leave unions? Group differences between workers in CCOO-Catalonia. Transf Eur Rev Labour Res 17(4):471-484

Kleibergen F, Paap R (2006) Generalized reduced rank tests using the singular value decomposition. J Econom 133(1):97-126

Kranendonk M, Beer P (2016) What explains the union membership gap between migrants and natives? $\mathrm{Br}$ J Ind Relat 54(4):846-869

Krings T (2009) A race to the bottom? Trade unions, EU enlargement and the free movement of labour. Eur J Ind Relat 15(1):49-69

Lee C-S (2005) International migration, deindustrialization and union decline in 16 affluent OECD countries, 1962-1997. Soc Forces 84(1):71-88

Leschke J, Vandaele K (2018) Explaining leaving union membership by the degree of labour market attachment: exploring the case of Germany. Econ Ind Democr 39(1):64-86

Lillie N (2010) Bringing the offshore ashore: transnational production, industrial relations and the reconfiguration of sovereignty. Int Stud Quart 54(3):683-704

Luttmer EF (2001) Group loyalty and the taste for redistribution. J Polit Econ 109(3):500-528

Magnani E, Prentice D (2003) Did globalization reduce unionization? Evidence from US manufacturing. Lab Econ 10(6):705-726

Marino S, Penninx R, Roosblad J (2015) Trade unions, immigration and immigrants in Europe revisited: unions attitudes and actions under new conditions. Comp Migrat Stud 3(1):1-16

Mayda AM, Rodrik D (2005) Why are some people (and countries) more protectionist than others? Eur Econ Rev 49(6):1393-1430

McKinnish T (2008) Panel data models and transitory fluctuations in the explanatory variable. In: Millimet DL, Smith JA, Vytlacil EJ (eds) Modelling and evaluating treatment effects in econometrics. Emerald, New York, pp 335-358

Meijer E, Spierdijk L, Wansbeek T (2015) Measurement error in panel data. In: Baltagi BH (ed) The Oxford handbook of panel data, vol 21. Oxford University Press, Oxford, pp 325-356

Munshi K (2003) Networks in the modern economy: Mexican migrants in the US labor market. Quart J Econ 118(2):549-599

Norwegian Centre for Research Data (2014). ESS round 7: European social survey round 7 data. Data file edition 2.2 
OECD (2019) . OECD.Stat, database, Organization for the Co-operation and Economic Development. https://doi.org/10.1787/data-00285-en

Penninx R, Roosblad J (2000) Trade unions, immigration, and immigrants in Europe, 1960-1993, vol 1. Berghahn Books, New York

Potrafke N (2010) Labor market deregulation and globalization: empirical evidence from OECD countries. Rev World Econ 146(3):545-571

Potrafke N (2013) Globalization and labor market institutions: international empirical evidence. J Comp Econ 41(3):829-842

Rathelot R, Safi M (2014) Local ethnic composition and natives' and immigrants' geographic mobility in France, 1982-1999. Am Sociol Rev 79(1):43-64

Razin A, Sadka E, Swagel P (2002) Tax burden and migration: a political economy theory and evidence. J Public Econ 85(2):167-190

Rodrik D (1998) Why do more open economies have bigger governments? J Polit Econ 106(5):997-1032

Rosetti N (2019) Do European trade unions foster social solidarity? Evidence from multilevel data in 18 countries. Ind Relat J 50(1):84-101

Schnabel C (2013) Union membership and density: some (not so) stylized facts and challenges. Eur J Ind Relat 19(3):255-272

Schnabel C (2020) Union membership and collective bargaining: trends and determinants, LASER Discussion Papers-Paper No. 121

Schnabel C, Wagner J (2007) Union density and determinants of union membership in 18 EU countries: evidence from micro data, 2002/03. Ind Relat J 38(1):5-32

Statistics Austria (2016) STATcube-Statistische Datenbank von Statistik Austria. Statistics Austria database, Statistics Austria. http://statcube.at

Statistik Austria (2021) Einbürgerungen seit 1946 nach Bundesland bzw. Ausland. https://www.statistik. at/web_de/statistiken/menschen_und_gesellschaft/bevoelkerung/einbuergerungen/022746.html

Swaffield JK (2001) Does measurement error bias fixed-effects estimates of the union wage effect? Oxford Bull Econ Stat 63(4):437-357

Vachon TE, Wallace M, Allen H (2016) Union decline in a neoliberal age: globalization, financialization, European integration, and union density in 18 affluent democracies. Sociol Res Dyn World 2:1-22

Visser J (2019) ICTWSS: Database on institutional characteristics of trade unions, wage setting, state intervention and social pacts in 55 countries between 1960 and 2017. version 6.0. http://www.uvaaias.net/en/ictwss

Winter-Ebmer R (2003) Benefit duration and unemployment entry: a quasi-experiment in Austria. Eur Econ Rev 47:259-273

Winter-Ebmer R, Zweimüller J (1996) Immigration and the earnings of young native workers. Oxf Econ Pap 48(3):473-491

Winter-Ebmer R, Zweimüller J (1999) Do immigrants displace young native workers: the Austrian experience. J Popul Econ 12(2):327-340

Wrench J (2004) Trade union responses to immigrants and ethnic inequality in Denmark and the UK: the context of consensus and conflict. Eur J Ind Relat 10(1):7-30

Zincone G, Caponio T (2006) The multilevel government of migration. In: Penninx R, Berger M, Kraal K (eds) The dynamics of international migration and settlement in Europe: a state of the art. Amsterdam University Press, Amsterdam, pp 269-304

Zweimüller J, Winter-Ebmer R, Lalive R, Kuhn A, Wuellrich J-P, Ruf O, Büchi S (2009) Austrian Social Security Database. Technical Report 903, The Austrian Center for Labor Economics and the Analysis of the Welfare State

Publisher's Note Springer Nature remains neutral with regard to jurisdictional claims in published maps and institutional affiliations. 